\title{
Lifelong Learning Application: Mobile Application to Promote Lifelong Learning and Introduce Educational Institutions
}

\author{
Wongpanya Nuankaew*, ${ }^{*}$, Pratya Nuankaew ${ }^{2}$, Kanakarn Phanniphong ${ }^{3}$ \\ ${ }^{1}$ Faculty of Information Technology, Rajabhat Mahasarakham University, 44000, Thailand \\ ${ }^{2}$ School of Information and Communication Technology, University of Phayao, 56000, Thailand \\ ${ }^{3}$ Faculty of Business Administration and Information Technology, Rajamangala University of Technology Tawan-Ok, 20110, Thailand
}

\section{A R T I C L E I N F O}

Article history:

Received: 28 May, 2017

Accepted: 29 July, 2017

Online: 21 August, 2017

Keywords:

Lifelong Learning Application,

Datamining in Education,

Students' Academic Achievement,

Education Engineering Systems

\begin{abstract}
A B S T R A C T Education is the raising of the thinking process and developing the mind in a broader perspective. However, education that is comprehensive and appropriate to the individual according to its potential, ability and skill is too hardest to describe. Thus, matching and referral institutions, including education model that suits the person's behavior has been receiving attention. The purpose of this research is to study and develop the applications that support the development of the learner's education process with the highest degree of achievement. The material and method are consisting of five main processes, including 1) requirement definition, 2) system and software design, 3) implementation and unit testing, 4) integration and system testing, and 5) operation and maintenance. The data collection were collected from 431 samples, which divided into 4 targets; 186 high school students at Phadungnaree School, Maha Sarakham province, 191 university students at Rajabhat Mahasarakham University, 12 head of institutions at Phadungnaree School and Rajabhat Mahasarakham University, and 42 secondary teachers and university lecturers at Phadungnaree School and Rajabhat Mahasarakham University. According to the results of research, it is indicated that the total satisfaction toward the application are highest, which is equal to 4.32, and the groups with the highest levels of satisfaction are university students, which is equal to 4.43. It can be concluded that the application is appropriate and it is advisable for students who wish to study at university.
\end{abstract}

\section{Introduction}

Nowadays, scientific and technological progress than in the past, it seems that everything around them with the facilities and the living is easy. Technology can provide support and resolve problems in every field of knowledge. Transferring of technology and know-how is fast and comprehensive for various purposes and reasons.

Even so, justice and equality in accessing development and knowledge of the individual remain questions. According to the Sustainable Development of the United Nations (UN), it mentioned that the need for "A world with equitable and universal

"Correponding author: Wongpanya Nuankaew, Rajabhat Mahasarakham University, Thailand | Email: wongpanya.nu@rmu.ac.th access to quality education at all levels, to health care and social protection, where physical, mental and social well-being is assured [1]'. Many questions arise from this mission, such as how to achieve the goals, what are the main hurdles, where to solve the problem, who to deal with, and many more.

One of the ways to achieve this, the international community has focused on health, education and social reforms involving individuals, systems and information enormously. The 2015 World Education Forum held at Incheon, South Korea, been shown that the future education vision is fully taken up with an offer of equal and fair quality to educational institutions as well as the promotion of lifelong learning opportunities for all learners [2]. 
These two ideas discuss the relationship with Goal 4 of the United Nations Sustainable Development Goal, which is quality education and ensures that quality in education is equal and promotes equality. Everybody's lifelong learning opportunity [3, 4]. Based on the importance of the above, the research team studied the components of the recommendations for selecting the right university for the right student, and developed it as an application on the device, which is the intention of the international community, as shown in Figure 1.

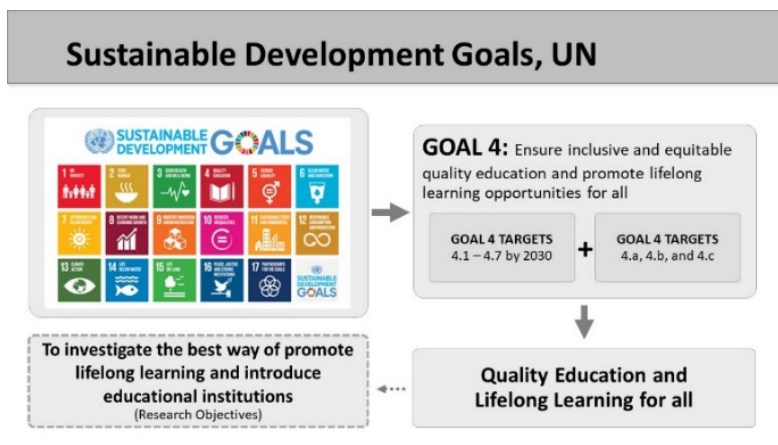

Figure 1. The importance of the research

Figure 1 illustrates the importance and relevance of research development to the goals of the international community, which is a complex problem when attempting to match the most appropriate student to the institution. Moreover, this research is an extension of Nuankaew's research [5], which reflects the research problem as shown in Figure 2 and Figure 3.

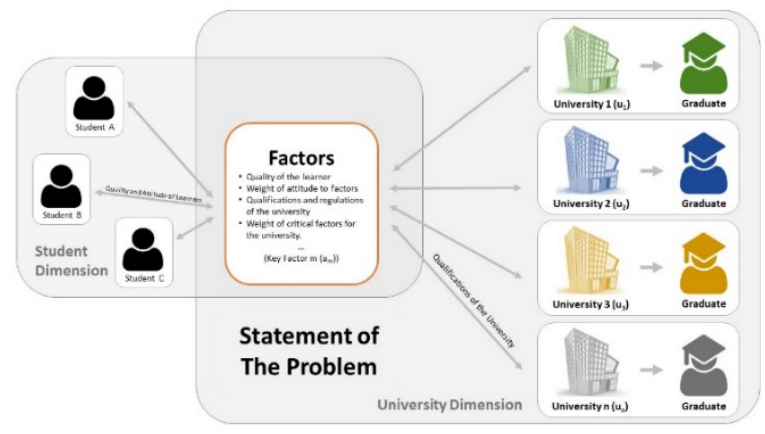

Figure 2. The Research Problem [5]

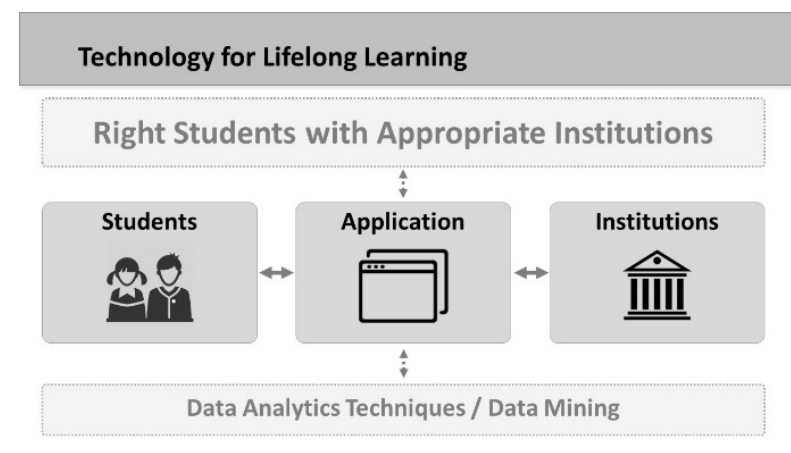

Figure 3. Using Modern Technology for Lifelong Learning

Once the research is done, the final step before publishing the application to the public is known and applied, the team has evaluated the performance and satisfaction of the application, which consists of five parts: 1) requirement definition, 2) system and software design, 3) implementation and unit testing, 4) integration and system testing, and 5) operation and maintenance as demonstrated in Figure 4. The details of each topic are clearly described in the material and methods sections.

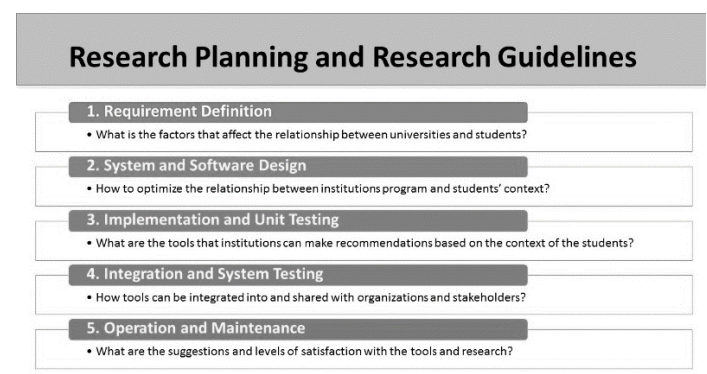

Figure 4. Research Planning and Research Guidelines

To complete the research work, the structure of the document is as follows: Literary review is compiled and presented in Section II. Section III defines and describes the variables, including a summary of all operational procedures. Section IV presents the results of the operation and discusses. Finally, Section V provides conclusions and future works, respectively.

\section{Literature Review}

Research and development tools for educational application consist of a combination of disciplines, including science, social sciences, education, engineering, and technology that can develop potential and success. From the research problem needed to solve the problem of matching learners to appropriate institutions. The research team summarized and collected relevant literature to present the ideas in the following topics.

\subsection{Students' Academic Achievement}

Measurement of student success can be done in several ways and factors. According to the research of Dougherty and Sharkey [6], it was found that factors contributing to the improvement of student achievement were three parts: grade point averages (GPAs), emotional competence, and social support. It offers a model of path analysis for mediation models with social support and emotional ability that reflects students' impact on GPA and achievement.

While the invisible academic relationship between students and institutions is contributing to academic achievement [7]. It clearly demonstrates that attitudes toward academia, along with their academic achievements, contribute to institutional decisionmaking and academic success. Another example of research related to academic achievement are dimension of learning styles and students' academic achievement [8]. It is suggested that an appropriate learning style could help students to achieve a good academic record in any subject they learned.

Therefore, it is concluded that the development of students to attain academic achievement must be in every dimension including the students, the learning environment, the education system and the stakeholders [9-11].

\subsection{Educational Technology and Students' Performance}

Students' performance refers to the academic performance of a student, which encompasses the processes that promote student success in education. While technology enables life and education is easy. Various tools and methods are used consists in teaching and learning in the classroom, including using of a mobile learning management system with online students [12], an applications on 
the mobile to introduce the appropriate institution [5], prediction of students' academic failure [13], and using an educational computer program to enhance student performance [14].

No matter what tools or technologies are used to support education. Educational measurement and educational standards are still needed as a basis for the student's developmental and educational success. Therefore, the choice of tools must take into account the learning goals and achievement that will occur with the students.

\subsection{Education System and Limitations}

It cannot be denied that education is not only in the classroom, although education is attempting to develop a structure or form that is appropriate for the learner's age and environment. But, the outof-class study and self-learning are surprisingly remarkable. Meanwhile, getting the knowledge and answers from the Internet can be easy and convenient. But there are few percent verified and accepted. Therefore, the education system must integrate modern technology and limit the scope of finding the correct and appropriate knowledge for the learners.

Some researches offer a dimension of education related to the education system in Thailand. Based on the research report of Sitthipon Art-in [15], it was found that the current situation and need in learning management for developing the analytical thinking of teachers in basic education of Thailand as overall in the high level. The problem with the lowest level of performance is that teachers have the ability to design and create learning plans to develop students' analytical thinking.

While research on patterns and methods of education affecting students has been discussed [16]. It is concluded that the students should be allowed to construct the body of knowledge by themselves through the Open Approach, which they are interested in and motivated to face of the problem situation. Therefore, in order to understand Thailand's education system and education structure, the following topics are divided into 2 main themes: 1 ) Thailand's formal education system, and 2) lifelong learning style.

\subsubsection{Thailand's Formal Education System}

In the public domain of Thailand, the education system is free and takes 12 years to complete. The study structure follows the "63-3" project, with 6 years of primary education, 3 years of lower secondary level and 3 years of upper secondary level. As displayed in Figure 5, elementary education is classified as Prathom 1-6, which correlates to Grades 1-6. While, secondary education is classified as Matthayom 1-6 and correlates to Grades 7-12.

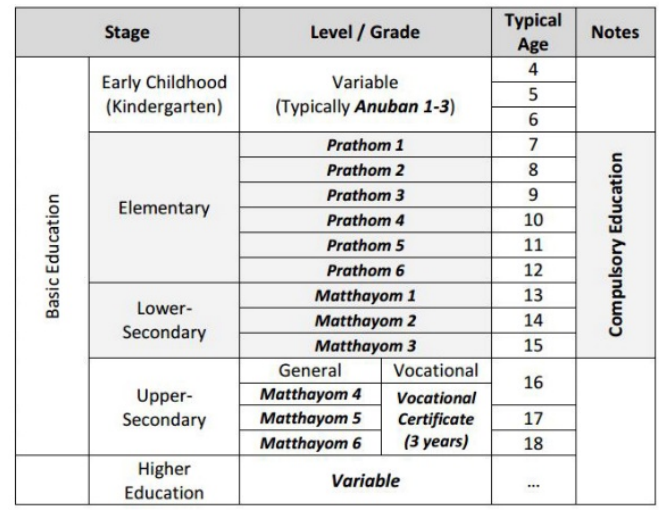

Figure 5. Thailand's Formal Education System

\subsubsection{Lifelong Learning Style}

In view of its success, to learn what love is one of the factors. It can be supported by Cabi's research [17]. It is recommended that students find out their own learning styles and choose the most effective strategies for their learning. It is important to learn for lifelong learning. In the definition of learning style, it is a set of techniques that make it easy for individuals to learn about yourself and learn to make the learning process information in a manner that is stable.

Theories of learning styles are continually evolving from the past. One popular theory is that Kolb's learning model, in which individual learning styles are cyclical [18]. There are four learning style in this cycle, including Abstract Conceptualization (AC), Active Experience (AE), Concrete Experience (CE), and Reflective Observation (RO). The student learning model is represented by four basic types of learning, and the individual's score indicates the most appropriate learning style as shown in Table I.

Table I. Four basic types of learning styles

\begin{tabular}{|c|l|l|}
\hline Types & Elements & \multicolumn{1}{c|}{ Meaning } \\
\hline Accommodating & AE and CE & $\begin{array}{l}\text { Engage in real experiences and enjoy learning } \\
\text { from exploration and application and search. } \\
\text { They are open for strange thoughts. }\end{array}$ \\
\hline Assimilating & AC and RO & $\begin{array}{l}\text { They like structured and systematic } \\
\text { knowledge. The knowledge presented must be } \\
\text { detailed, structured and include visual and } \\
\text { audio components. }\end{array}$ \\
\hline Converging & AC and AE & $\begin{array}{l}\text { The details are very important for those } \\
\text { individuals and they are trying to understand } \\
\text { by studying each section first. They learn to } \\
\text { new knowledge first, then use it and not be } \\
\text { afraid to make mistakes while learning. }\end{array}$ \\
\hline Diverging & CE and RO & $\begin{array}{l}\text { They like learning by observing real } \\
\text { experiences instead of joining them. Need } \\
\text { systematic presentation of knowledge on } \\
\text { various topics. These individuals will be } \\
\text { successful from the perspective of real cases. }\end{array}$ \\
\hline
\end{tabular}

Learning styles have a significant relationship to the nature of teaching and learning [18]. Therefore, teaching and learning management has an impact on the educational system. Laal, et al. [19] summarizes a group of lifelong learning and education systems, consisting of three main groups: formal learning, nonformal learning, and informal learning as details are shown in Table II.

Table II. Education systems

\begin{tabular}{|l|l|}
\hline \multicolumn{1}{|c|}{ Categories } & \multicolumn{1}{c|}{ Definitions and Examples } \\
\hline $\begin{array}{l}\text { Formal Learning } \\
\text { (Formal Education) }\end{array}$ & $\begin{array}{l}\text { It is learning that takes place in an organized and } \\
\text { structured context. } \\
\text { Examples: } \\
\text { - Study in school or academic institutions } \\
\text { - Training in a workplace or through an expert } \\
\text { - Learning with curriculum or structured courses }\end{array}$ \\
\hline $\begin{array}{l}\text { Non-Formal } \\
\text { Learning }\end{array}$ & $\begin{array}{l}\text { It is driven by activities that are not clearly defined. } \\
\text { Examples: } \\
\text { Education) }\end{array}$ \\
\hline $\begin{array}{l}\text { Informal Learning } \\
\text { - Training in communities } \\
\text { - Groups of adjustment according to students' needs. }\end{array}$ \\
$\begin{array}{l}\text { It relates to learning from the daily activities of family } \\
\text { and work. It is often called experiential learning. } \\
\text { Examples: } \\
\text { - Family activities } \\
\text { - Education to improve individuals }\end{array}$ \\
\hline
\end{tabular}




\subsection{Technology Support and Solutions}

This section provides information and literature about applying technology related to education in three topics: 1) Data mining in education, which refers to the use of data mining technology for educational research. 2) Mobile web application technology, which offers technology to support and develop research tools. 3) Software development methodology, which is a process and step to develop an effective and complete application.

\subsubsection{Data Mining in Education}

Data mining technology is searching for patterns and processes that have values from a large number of data. In the education system, vast amounts of information being analyzed and synthesized for the main purpose is to develop the capacity of students and learners' potential, to achieve the academic achievement of the learner.

Examples of research such as Costa's research, which presents the results of evaluating the effectiveness of educational data mining techniques for early prediction of students' academic failure [13]. Natek's research demonstrates the application of data mining technologies to the analysis and development of decision models for planning and management in higher education institutions [20]. And the important example is an institution recommender system based on student context and educational institution in a mobile environment [5] that extends to this research. This work has been carried out to complete the process of the System Development Life Cycle (SDLC), which consists of seven steps: problem recognition, feasibility study, analysis, design, construction, conversion, and maintenance.

\subsubsection{Mobile Web Application Technology}

Nowadays, access to information and the internet is easy with the communication device everyone has. It is a mobile phone. Many applications have been developed and used to support educational systems.

For example, Briz-Ponce's research [21], which presents research findings on different drivers and factors that may affect student needs with mobile technology for learning. Yoo and Lee's research [22] uses a mobile application technology to develop knowledge and teaching for nursing students. Simonova and Poulova's research [23] applied mobile technology for learners' preferences in mobile-assisted higher education.

From the examples that bring mobile computing technology into use in various fields. As well as, the research team was interested in developing tools to support education, it developed a mobile for introducing appropriate institutions to students [5]. The research was extremely interesting, and the research team further developed the research that was proposed to assess application satisfaction and efficiency, which is presented in the next section.

\subsubsection{Software Development Methodology}

In software engineering, software development methodology is software development. It is a different procedure which consists of activities that are intentionally planned and managed better. It is often perceived as a subset of the development life cycle. Such methods may include predefined definitions of deliverables and inventions defined by project teams to develop or maintain programs. There are several software development methodology such as waterfall, prototyping, iterative and incremental development, spiral development, rapid application development, extreme programming and various types of agile methodology.

In this research, the waterfall model is used to assemble processes to develop applications and software for quality and performance, which consisting of five components: requirements engineering, design and implementation, testing, release, and maintenance as shown in Figure 6.

\section{The Waterfall Model in Large-Scale Development}

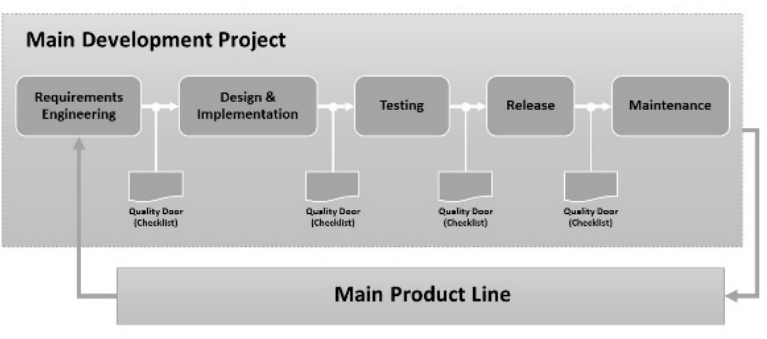

Figure 6. The Waterfall Development

\subsubsection{Requirements Engineering}

At this stage, the needs and significance of the problem are identified and documented at the abstract level. After that the specifications will be refined so that they can be used for design and operation. Specifications are stored in the required repository, and the requirements to be applied are selected from the repository. A number of requirements, depending on the resources available for the project. The quality will check that all terms are understood and agreed upon and documented. It also requires monitoring relevant stakeholders and solutions to support strategies and objectives.

\subsubsection{Design and Implementation}

At the stage of architectural design was created documented. After that, system development started. Developers also perform basic unit tests before code development during the testing phase. The quality checklist verifies that the architecture has been evaluated for deviation from the specifications compared to predetermined quality decisions.

\subsubsection{Testing}

In this period, integration has been tested on quality and functionality. In order to decide whether the system is usable, it will measure performance in the lab such as throughput. Because the goal is to solve the problem perfectly, then the test will be performed on a variety of different configurations. Phase results will be reviewed according to a checklist to track whether the system has been validated.

\subsubsection{Release}

In the release phase the product is returned into a shippable state. The release documentation is the final step, which contains documentation for installation and usage for the user. In addition, creating instructions for the system must be programmed. The build guide can be used to enable and disable features of the main line product to customize the system to meet the specific needs of the target. Quality must ensure that the response meets the needs of the target. The final result is delivered for the intended purpose and meets the quality requirements. 


\subsubsection{Maintenance}

After the product has been released, it must be maintained. That is, if the user encounters a problem in the product, the report is developed and encouraged to solve the problem. If the problem is due to an error in the product package, the system update will be sent to the user.

\section{Material and Methods}

After gathering the literature and scope of the research area, this step details the material and the method. It consists of five main stages: 1) requirement definition, 2) system and software design, 3) implementation and unit testing, 4) integration and system testing, and 5) operation and maintenance as shown in Figure 7.

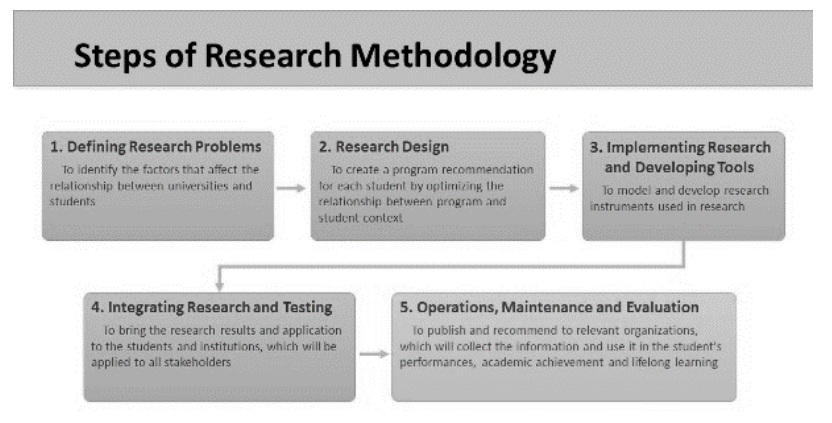

Figure 7. Steps of Research Methodology

\subsection{Defining Research Problems}

The objective of this step is to identify the factors that affect the relationship between universities and students [24]. This process was conducted by designing a questionnaire asking for opinions and attitudes from 256 students at two universities: University of Phayao and Rajabhat Maha Sarakham University. After receiving information from the respondents, the text mining process was analyzed to model and identify factors that are important to students and institutions.

The results show that the performance of the model employs two important factors; education system and interested in study, which are used to predict student's interest in higher education. While, the decision tree model with two depth levels was most appropriate with $81.46 \%$ accuracy as shown in Figure 8.

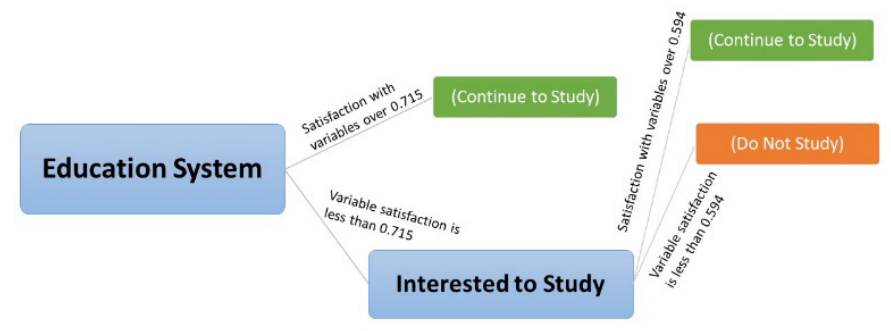

Figure 8. Decision Tree Model to Predict Student's Interest [24]

\subsection{Research Design}

After discovering that the education system and student interest have a bearing on the decision to study in higher education, the research team studied the characteristics of attitudes that resulted in the selection of educational programs, as well as educational institutions. Based on the data collected from 885 students of three higher educations, including Rajabhat Mahasarakham University, Mahasarakham University, and University of Phayao and the results of model analysis, the accuracy points out 19 significant factors; 15 factors of student context and 4 factors of program context, which is appropriate used to introduce institutions for the style and attitude of the students as show in Table III.

Table III. Summary of significant factors

\begin{tabular}{|c|c|}
\hline Characteristics & Features \\
\hline $\begin{array}{l}\text { Student's } \\
\text { Interests }\end{array}$ & $\begin{array}{l}\text { - Interest in studying } \\
\text { - Career path } \\
\text { - Identity of the University } \\
\text { - Obtained knowledge } \\
\text { - Education system }\end{array}$ \\
\hline $\begin{array}{l}\text { Student's } \\
\text { Characteristics }\end{array}$ & $\begin{array}{l}\text { - Ability } \\
\text { - Skills } \\
\text { - Knowledge } \\
\text { - Learning style } \\
\end{array}$ \\
\hline $\begin{array}{l}\text { Student's } \\
\text { Environment }\end{array}$ & $\begin{array}{l}\text { - Social capital and Economic } \\
\text { - Trust in institutions } \\
\text { - Personal decision } \\
\text { - Family income } \\
\text { - Community } \\
\text { - Purpose of study }\end{array}$ \\
\hline $\begin{array}{l}\text { Programs' } \\
\text { Context }\end{array}$ & $\begin{array}{l}\text { - The popularity of the University } \\
\text { - Curriculum } \\
\text { - Education standard } \\
\text { - Quality assurance }\end{array}$ \\
\hline
\end{tabular}

In addition, the model has $76.50 \%$ accuracy, showing that the generated model represents the appropriate relationship between student's context and programs' context for the proposed program recommendation, with 53 rules as shown in Figure 9.

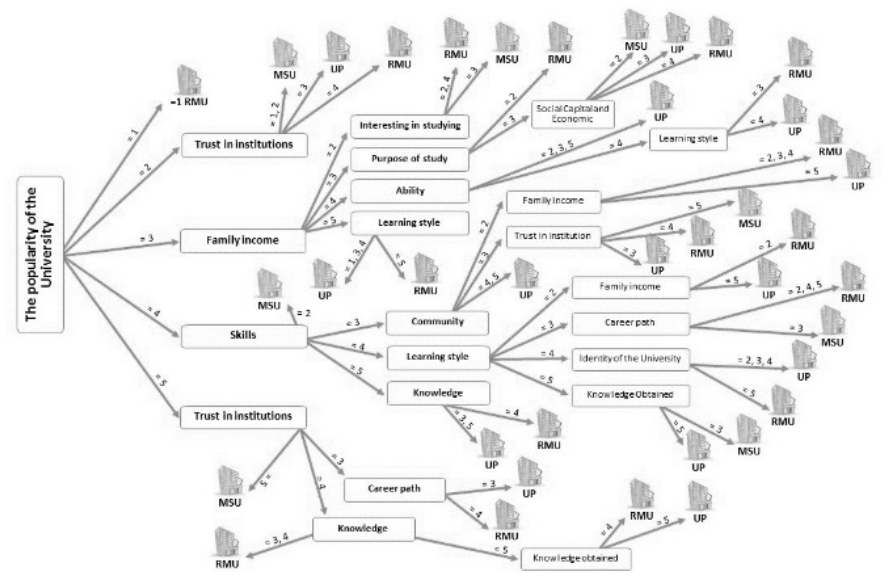

Figure 9. Decision Tree Model to Introduce Institutions

\subsection{Implementing Research and Developing Tools}

After knowing and discovering the factors that can be used to predict an interest in further education and behavioral characteristics that are consistent with, and appropriate educational programs and institutions. The application for introducing educational institutions based on student's context and educational institution in a mobile environment has been developed, which using the mobile web apps function [5]. It was applied to 1,109 students from 3 campuses; Rajabhat Mahasarakham University, Mahasarakham University, and University of Phayao to conduct and test the application, which the interface of the application is shown in Table IV. 
W. Nuankaew et al. / Advances in Science, Technology and Engineering Systems Journal Vol. 2, No. 3, 1556-1564 (2017)

Table IV. Application interface

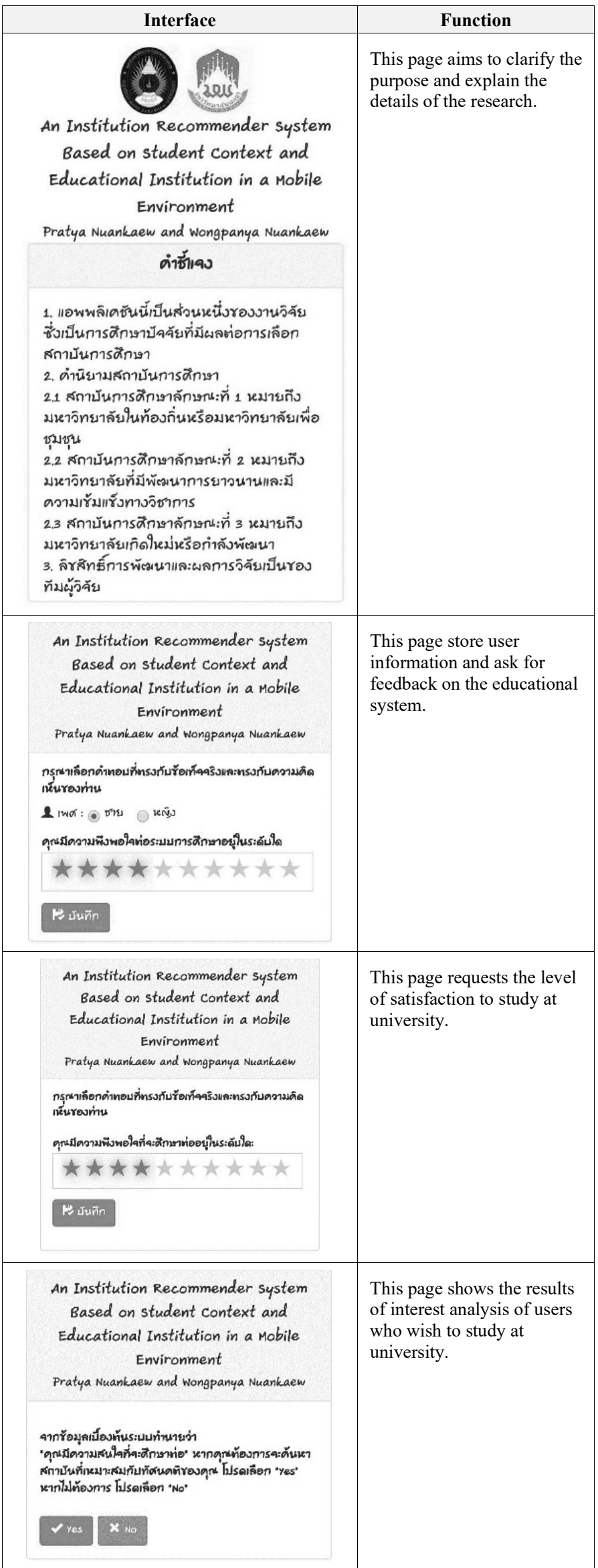

www.astesj.com

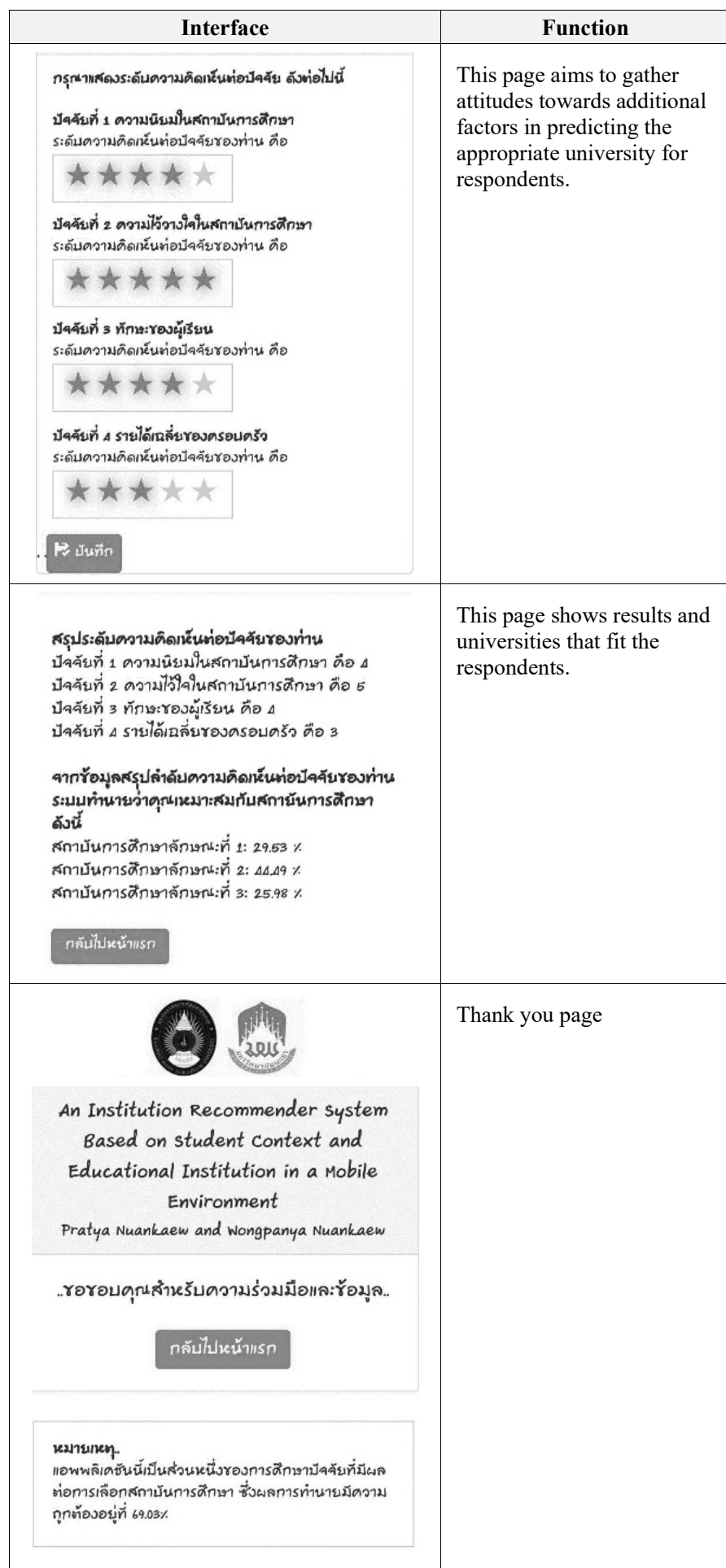

\subsection{Integrating Research and Testing}

To bring the application to the students, institutions and all stakeholders. The research team applied the application to the university's public relations activities and curriculum promotion activities. At the same time, the research team collected the survey data on attitudes and academic achievement of students in the upper secondary school that represent the academic relationship between academic achievement and institutions [7].

The survey found that the Grade Point Average (GPA), and school types had an impact and affects the attitudes toward the 
selection institutions, which is consistent to student's attitude, their academic achievement and research's factors.

\subsection{Operations, Maintenance and Evaluation}

This step is the final stage of the research process, which is a key topic in the research process. The goal of this step is to publish and recommend to relevant organizations, which will provide the application and use it in the student's performances development, development of learning achievement and promoting lifelong learning.

The process at this stage consists of promoting the application and evaluation of applications in all dimensions, including finding the level of satisfaction toward the application, and evaluate the performance of the application, as elements as shown in Figure 10.

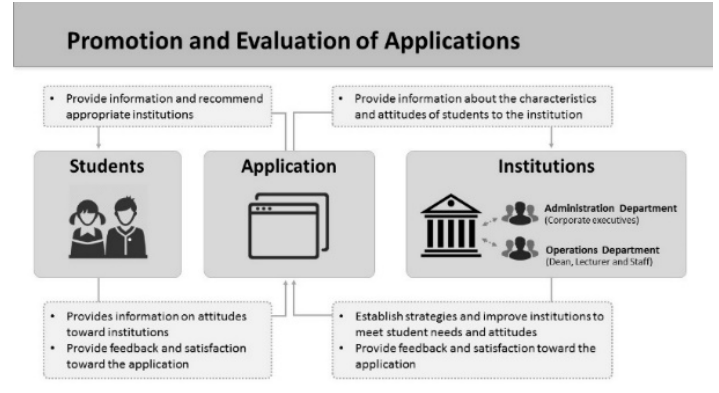

Figure 10. Process of Promotion and Evaluation of Applications

From Figure 10, it shows the process of promotion and evaluation of applications, which consist of two dimensions, including the student dimension and the institution dimension.

To carry out the full procedure as planned, the research team had planned operation consists of four stages: 1) promoting and introducing the application, 2) providing results and information from the application, 3) collecting feedback and satisfaction from the users, and 4) summary of suggestions and analyze the level of satisfaction. The details of each step is explained in the next section.

\subsubsection{Promoting and Introducing the Application}

The samples were selected to promote the application consists of 4 groups, including 186 high school students at Phadungnaree School, Maha Sarakham province, 191 university students at Rajabhat Mahasarakham University, 12 head of institutions at Phadungnaree School and Rajabhat Mahasarakham University, and 42 teachers and lecturers at Phadungnaree School and Rajabhat Mahasarakham University.

\subsubsection{Providing Information from the Application}

After presenting and introducing the application, when the user provides information, attitudes, and level of satisfaction to the application. The application performs data synthesis and presents all results to the user.

For example, students enter the attitude toward the key factor. After that, the application calculates the predictive function and introduces the appropriate institution to the student. Another example is that the application provides an overview of the user feedback to the university, each of which factors the institution can use to improve its potential. At the same time, the research team was able to gather information, attitudes and opinions to further improve and develop the research.

\subsubsection{Collecting feedback and satisfaction}

Gathering feedback and satisfaction levels on the application, the research team has designed and constructed a questionnaire to evaluate and ask satisfaction, which consists of four key areas to ensure compliance with software quality including 1) functional requirement test, 2) functional test, 3 ) usability test, and 4) security test.

However, user and volunteer participation is strictly voluntary. Apart from the results and the predictions of the application, the participants do not receive any compensation or items for participation. Participants were asked to honestly score statements on a 5-point Likert scale, ranging from 1 to 5 , with 1 indicating little to no agreement and 5 indicating high agreement with statements.

\subsubsection{Analyze the Level of Satisfaction}

At this stage, data analysis from the sample is based on simple statistical analysis, which includes the average and standard deviation. Then analyze the results and summarize key points from the recommendations and suggestions.

\section{Results and Discussion}

According to the research team has designed the research protocol into five parts, The process has been completed in four stages [5, 7, 24]: 1) defining research problems [24], 2) research design, 3) implementing research and developing tools [5], and 4) integrating research and testing [7]. There is still another important step, the final step is operation, maintenance and evaluation.

Therefore, this section is divided into two parts: reporting on the results of the final stage of the research methodology and discussion topics.

\subsection{Results of operations, maintenance and evaluation}

The reported results of operations are presented survey results were compiled from four sample groups: 1) high school students, 2) university students, 3) head of institutions, and 4) secondary teachers and university lecturers. It has a variety of views and opinions as summarized in Table V.

Table V. Summary of sample groups

\begin{tabular}{|l|l|}
\hline \multicolumn{1}{|c|}{ Sample Groups } & \multicolumn{1}{c|}{ Number and Source } \\
\hline Gender & 228 female $(52.90 \%)$ and 203 male $(47.10 \%)$ \\
\hline $\begin{array}{l}\text { High School } \\
\text { Students }\end{array}$ & $\begin{array}{l}186 \text { students }(43.16 \%) \text { from Phadungnaree School, } \\
\text { Maha Sarakham province, Thailand }\end{array}$ \\
\hline $\begin{array}{l}\text { University } \\
\text { Students }\end{array}$ & $\begin{array}{l}\text { 191 students }(44.32 \%) \text { from Rajabhat Mahasarakham } \\
\text { University, Maha Sarakham province, Thailand }\end{array}$ \\
\hline $\begin{array}{l}\text { Head of } \\
\text { Institutions }\end{array}$ & $\begin{array}{l}\text { 12 school administrators (2.78\%) from Phadungnaree } \\
\text { School and } 10 \text { administrators, department heads and } \\
\text { deans from Rajabhat Mahasarakham University. }\end{array}$ \\
\hline $\begin{array}{l}\text { Secondary } \\
\text { Teachers and } \\
\text { University } \\
\text { Lecturers }\end{array}$ & $\begin{array}{l}\text { 42 teachers (9.74\%) from Phadungnaree School and } \\
\text { lectures from Rajabhat Mahasarakham University. }\end{array}$ \\
\hline \begin{tabular}{l} 
Total: \\
\hline
\end{tabular} & \begin{tabular}{l} 
431 Samples \\
\hline
\end{tabular}
\end{tabular}

From Table V, it shows the details of the sample and the data collected. The data obtained from the survey is based on a 
questionnaire with questions on four main perspectives as shown in Table VI.

Table VI. Four main perspectives of the questionnaire

\begin{tabular}{|c|c|}
\hline $\begin{array}{l}\text { Perspectives and } \\
\text { Functions }\end{array}$ & Sub-topics and Details \\
\hline $\begin{array}{l}\text { Functional } \\
\text { Requirement } \\
\text { Test }\end{array}$ & 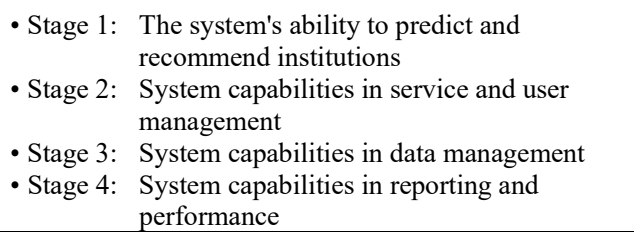 \\
\hline Functional Test & $\begin{array}{l}\text { - Stage 5: } \text { The accuracy of the results of the } \\
\text { processing } \\
\text { - Stage 6: The speed of processing of the application } \\
\text { - Stage 7: Reliability of the program } \\
\text { - Stage 8: } \begin{array}{l}\text { Coverage of programs developed for the } \\
\text { enterprise }\end{array}\end{array}$ \\
\hline Usability Test & $\begin{array}{l}\text { - Stage 9: Ease of use and user friendliness } \\
\text { - Stage 10: Appropriateness of color, size and font of } \\
\text { the application } \\
\text { - Stage 11: The appropriateness of using text to } \\
\text { describe and convey meaning } \\
\text { - Stage 12: The appropriateness of using the symbols or } \\
\text { images } \\
\text { - Stage 13: Standards and design criteria for the user } \\
\text { interface } \\
\text { - Stage 14: Appropriateness of interaction with users }\end{array}$ \\
\hline Security Test & $\begin{array}{c}\text { - Stage 15: Controlling access to systems, authorizing, } \\
\text { and data access control } \\
\text { - Stage 16: System failure prevention and data entry }\end{array}$ \\
\hline
\end{tabular}

After designing the questionnaire and conducting the survey on selected samples, survey results are analyzed and summarized in Table VII.

Table VII. Overview of application satisfaction

\begin{tabular}{|c|c|c|c|c|c|}
\hline \multirow{2}{*}{$\begin{array}{c}\text { Perspectives } \\
\text { and Functions }\end{array}$} & \multicolumn{4}{|c|}{ Sample Groups } & \multirow{2}{*}{ Total: } \\
\hline & $\begin{array}{l}\text { High School } \\
\text { Students }\end{array}$ & $\begin{array}{l}\text { University } \\
\text { Students }\end{array}$ & $\begin{array}{l}\text { Head of } \\
\text { Institutions }\end{array}$ & $\begin{array}{l}\text { Teachers and } \\
\text { Lecturers }\end{array}$ & \\
\hline $\begin{array}{l}\text { Functional } \\
\text { Requirement Test } \\
\text { - Stage } 1 \\
\text { - Stage } 2 \\
\text { - Stage } 3 \\
\text { - Stage } 4 \\
\end{array}$ & $\begin{array}{l}4.36(0.51) \\
3.55(0.57) \\
3.62(0.55) \\
3.95(0.28)\end{array}$ & $\begin{array}{l}4.55(0.65) \\
4.23(0.76) \\
4.42(0.68) \\
4.35(0.74)\end{array}$ & $\begin{array}{l}4.33(0.49) \\
4.00(0.60) \\
4.00(0.60) \\
3.83(0.39)\end{array}$ & $\begin{array}{l}4.31(0.52) \\
3.74(0.59) \\
3.83(0.58) \\
3.93(0.51)\end{array}$ & $\begin{array}{l}4.44(0.58) \\
3.91(0.74) \\
4.00(0.72) \\
4.12(0.57)\end{array}$ \\
\hline $\begin{array}{l}\text { Functional Test } \\
\text { - Stage } 5 \\
\text { - Stage } 6 \\
\text { - Stage } 7 \\
\text { - Stage } 8\end{array}$ & $\begin{array}{l}4.24(0.44) \\
4.81(0.41) \\
3.76(0.51) \\
3.84(0.42) \\
\end{array}$ & $\begin{array}{l}4.42(0.60) \\
4.50(0.66) \\
4.33(0.76) \\
4.33(0.70) \\
\end{array}$ & $\begin{array}{l}4.50(0.52) \\
4.75(0.45) \\
3.50(0.52) \\
3.83(0.39) \\
\end{array}$ & $\begin{array}{l}4.43(0.50) \\
4.71(0.51) \\
3.91(0.62) \\
3.91(0.48) \\
\end{array}$ & $\begin{array}{l}4.35(0.53) \\
4.66(0.56) \\
4.02(0.70) \\
4.06(0.61)\end{array}$ \\
\hline $\begin{array}{l}\text { Usability Test } \\
\text { - Stage } 9 \\
\text { - Stage } 10 \\
\text { - Stage } 11 \\
\text { - Stage } 12 \\
\text { - Stage } 13 \\
\text { - Stage } 14\end{array}$ & $\begin{array}{l}4.90(0.30) \\
4.59(0.49) \\
4.12(0.38) \\
4.00(0.27) \\
4.76(0.47) \\
4.54(0.54)\end{array}$ & $\begin{array}{l}4.61(0.64) \\
4.48(0.59) \\
4.47(0.60) \\
4.38(0.67) \\
4.41(0.70) \\
4.41(0.67) \\
\end{array}$ & $\begin{array}{l}4.92(0.29) \\
4.67(0.49) \\
4.25(0.45) \\
4.00(0.43) \\
4.83(0.39) \\
4.67(0.49)\end{array}$ & $\begin{array}{l}4.98(0.15) \\
4.50(0.51) \\
4.10(0.37) \\
4.14(0.35) \\
4.69(0.47) \\
4.50(0.51)\end{array}$ & $\begin{array}{l}4.78(0.50) \\
4.54(0.54) \\
4.28(0.52) \\
4.18(0.53) \\
4.60(0.61) \\
4.49(0.60)\end{array}$ \\
\hline $\begin{array}{l}\text { Security Test } \\
\text { - Stage } 15 \\
\text { - Stage } 16\end{array}$ & $\begin{array}{l}4.18(0.51) \\
4.21(0.50)\end{array}$ & $\begin{array}{l}4.43(0.66) \\
4.52(0.64)\end{array}$ & $\begin{array}{l}3.92(0.52) \\
4.17(0.72)\end{array}$ & $\begin{array}{l}4.17(0.49) \\
4.19(0.55)\end{array}$ & $\begin{array}{l}4.28(0.59) \\
4.35(0.60)\end{array}$ \\
\hline Total: & $4.22(0.61)$ & $4.43(0.67)$ & $4.26(0.63)$ & $4.25(0.60)$ & $4.32(0.65)$ \\
\hline
\end{tabular}

From Table VII, it can be seen that the overall satisfaction of the application is at a high level (4.32). The highest satisfaction level was the student in the University, with the satisfaction level at 4.43. The second highest satisfaction level was the group of head of institutions, with the satisfaction level at 4.26. And the lowest level of satisfaction was high school student's satisfaction, at 4.22.
However, the recommendations from the survey can be summarized as important issues, such as how to publish the information to the stakeholders, how to use of data and the results of research into concrete action, future research will be carried out commercially or not, and how to monitor and evaluate learners in the long term.

\subsection{Discussion}

Refer to research process and research objectives, this research has completed all the stages from problem study to research evaluation. At every stage, the research team publishes the results in a step-by-step manner. All the published research, it has been expertly investigated and reviewed by a specialist. So the research results are truly qualitative, beneficial and useful. However, in the research discussion, the results were based on recommendations from experts who had received research feedback and comments from the participants from the survey to the discussions.

From the feedback and comments, it was found that the recommendations of the experts encouraged the research team to develop in-depth research that related to the research in education data mining. Because, most educators use knowledge-based learning processes for learners, there is a lack of tools that support and track student achievement. While the viewpoint of the general user, it is consistent with the ideas of the experts who need the tools and technology that can support, monitor, and predict students' achievement.

In future research, the research team clearly recognizes the required for substantial studies and development into concrete actions. Research focused on tracking the educational achievement of students at all levels, including the connections and relationships between the boundaries of each education level, resolving dropout rates during education, and increasing the promotion and development of lifelong learning.

\section{Conclusions}

After the research team has implemented and completed five main processes, including 1) the process of requirement definition, 2) the process of system and software design, 3) the process of implementation and unit testing, 4) the process of integration and system testing, and 5) the process of operation and maintenance.

The information that has been used in the research is composed of four groups: 186 high school students at Phadungnaree School, Maha Sarakham province, 191 university students at Rajabhat Mahasarakham University, 12 deans at Phadungnaree School and Rajabhat Mahasarakham University, and 42 secondary teachers and university lecturers at Phadungnaree School and Rajabhat Mahasarakham University.

The results indicated that the total satisfaction are highest, which is equal to 4.32, and the group with the highest level of satisfaction is group of university students, which is equal to 4.43. It can be concluded that the application is appropriate and it is advisable for students who wish to study at university.

By referring to the purpose of the research, the team can conclude that this research has been very successful. The developed applications are appropriate and should be widely disseminated. In the future, the research team has the idea to use this application to promote sustainable learning that is consistent with the personality of the individual. 


\section{Conflict of Interest}

The authors declare no conflict of interest.

\section{Acknowledgment}

This article has received financial support, research information, experts and resources from Phadungnaree School, Rajabhat Mahasarakham University, the University of Phayao, and Siam Crystal Consulting Co., Ltd. Bangkok, Thailand. The authors would like to thank the researchers, participants, and technicians for their efforts toward the completion of this research.

\section{References}

[1] H. B. Olaiya, "Transforming our world: The 2030 agenda for sustainable development \& international decade for people of African descent," 2016.

[2] J. Castaño Muñoz, C. Redecker, R. Vuorikari, and Y. Punie, "Open Education 2030: planning the future of adult learning in Europe," Open Learning: The Journal of Open, Distance and e-Learning, vol. 28, no. 3, pp. 171-186, 2013.

[3] M. Tight, "Lifelong learning: opportunity or compulsion?," British Journal of Educational Studies, vol. 46, no. 3, pp. 251-263, 1998.

[4] M. Sharples, "The design of personal mobile technologies for lifelong learning," Computers \& Education, vol. 34, no. 3, pp. 177-193, 2000.

[5] K. Pupara, W. Nuankaew, and P. Nuankaew, "An institution recommender system based on student context and educational institution in a mobile environment," in Computer Science and Engineering Conference (ICSEC), 2016 International, 2016, pp. 1-6.

[6] D. Dougherty and J. Sharkey, "Reconnecting Youth: Promoting emotional competence and social support to improve academic achievement," Children and Youth Services Review, vol. 74, pp. 28-34, 2017.

[7] W. Nuankaew, P. Nuankaew, S. Bussaman, and P. Tanasirathum, "Hidden academic relationship between academic achievement and higher education institutions," in Digital Arts, Media and Technology (ICDAMT), International Conference on, 2017, pp. 308-313.

[8] N. Omar, M. M. Mohamad, and A. N. Paimin, "Dimension of Learning Styles and Students' Academic Achievement," Procedia - Social and Behavioral Sciences, vol. 204, pp. 172-182, Aug. 2015.

[9] M. M. Hernández et al., "Elementary students' effortful control and academic achievement: The mediating role of teacher-student relationship quality," Early Childhood Research Quarterly, vol. 40, pp. 98-109, rd 2017.

[10] E. C. M. van Rooij, E. P. W. A. Jansen, and W. J. C. M. van de Grift, "Secondary school students' engagement profiles and their relationship with academic adjustment and achievement in university," Learning and Individual Differences, vol. 54, pp. 9-19, Feb. 2017.

[11] M. Yavuz and F. B. Kiyici, "Teachers' Opinions Regarding the Effects of the Usage of out-of-school Learning Environments on Students' Academic Achievement and Anxiety towards Science," Procedia - Social and Behavioral Sciences, vol. 106, pp. 2532-2540, Dec. 2013.

[12] I. Han and W. S. Shin, "The use of a mobile learning management system and academic achievement of online students," Computers \& Education, vol. 102, pp. 79-89, Nov. 2016.

[13] E. B. Costa, B. Fonseca, M. A. Santana, F. F. de Araújo, and J. Rego, "Evaluating the effectiveness of educational data mining techniques for early prediction of students' academic failure in introductory programming courses," Computers in Human Behavior, vol. 73, pp. 247-256, Aug. 2017.

[14] S. H. Chan, Q. Song, L. H. Rivera, and P. Trongmateerut, "Using an educational computer program to enhance student performance in financial accounting," Journal of Accounting Education, vol. 36, pp. 43-64, Sep. 2016.

[15] S. Art-in, "Current Situation and Need in Learning Management for Developing the Analytical Thinking of Teachers in Basic Education of Thailand," Procedia - Social and Behavioral Sciences, vol. 197, pp. 14941500, Jul. 2015.

[16] N. Satchakett and S. Art-in, "Development of Heuristics Problem Solving, and Learning Achievement of Grade 9 Students by Using Learning Management Focusing on Heuristics Approach in Thailand," Procedia Social and Behavioral Sciences, vol. 116, pp. 1011-1015, Feb. 2014.
[17] Cabi and S. Yalcinalp, "Lifelong Learning Considerations: Relationship Between Learning Styles and Learning Strategies in Higher Education," Procedia - Social and Behavioral Sciences, vol. 46, pp. 4457-4462, Jan. 2012.

[18] P. Nuankaew and P. Temdee, "Online Mentoring Model by Using Compatible Different Attributes," Wireless Pers Commun, vol. 85, no. 2, pp. 565-584, Nov. 2015.

[19] M. Laal, A. Laal, and A. Aliramaei, "Continuing Education; Lifelong Learning," Procedia - Social and Behavioral Sciences, vol. 116, pp. 40524056, Feb. 2014.

[20] S. Natek and M. Zwilling, "Student data mining solution-knowledge management system related to higher education institutions," Expert Systems with Applications, vol. 41, no. 14, pp. 6400-6407, Oct. 2014.

[21] L. Briz-Ponce, A. Pereira, L. Carvalho, J. A. Juanes-Méndez, and F. J. GarcíaPeñalvo, "Learning with mobile technologies - Students' behavior," Computers in Human Behavior, vol. 72, pp. 612-620, Jul. 2017.

[22] I.-Y. Yoo and Y.-M. Lee, "The effects of mobile applications in cardiopulmonary assessment education," Nurse Education Today, vol. 35, no. 2, pp. e19-e23, Feb. 2015.

[23] I. Simonova and P. Poulova, "Learners Preferences in Mobile-Assisted Higher Education,” Procedia Computer Science, vol. 104, pp. 174-182, Jan. 2017.

[24] P. Nuankaew, W. Nuankaew, and T. Thamma, " The Recommended System for the Relationship between Educational Programs and Students' Interests," in Digital Arts, Media and Technology (ICDAMT), International Conference on, 2016, pp. 308-313. 